\title{
Tsunami understanding media: Android-physics mobile learning to improve problem solving-skills and natural disaster preparedness
}

\author{
Annas Jati Abdillah ${ }^{1 *}$, Mundilarto ${ }^{2}$, Syazana Sulaiman $^{3}$ \\ ${ }^{1,2}$ Graduate School of Physics Education, Universitas Negeri Yogyakarta, Yogyakarta, Indonesia. \\ ${ }^{3}$ Material Science, Universiti Putra Malaysia, Institut Teknologi Maju (ITMA) 43400, Selangor, Malaysia
}

*Corresponding Address: annasjatiabdillah@gmail.com

\section{Article Info}

Article history:

Received: August $2^{\text {nd }}, 2020$

Accepted: October $22^{\text {nd }}, 2020$

Published: October $30^{\text {th }}, 2020$

\section{Keywords:}

Physics mobile learning;

Learning media;

Natural disaster preparedness;

Problem-solving;

Tsunami.

ABSTRACT

This research aimed to determine the effectiveness of the implementation of tsunami understanding media through Android-based physics mobile learning in improving students' problem-solving skills and natural disaster preparedness. This study employed quasi-experiment research with a nonequivalent control group design. This research subjects were fifty-six students of class XI IPA at SMA N 1 Kretek, Bantul, Yogyakarta. The sampling technique employed in this research was the simple random sampling technique to determine the experimental and control groups. The research data had been obtained through pretest and posttest in the form of essay tests. The data obtained were then analyzed using $\mathrm{N}$-gain. The analysis results were used to determine the effectiveness of the media using the Hotelling's Trace test in MANOVA test analysis. Normally distributed and homogeneous data are required to perform the multivariate analysis. The results showed that the tsunami understanding media through Android-based physics mobile learning improved students' problem-solving skills and natural disaster preparedness compared to the learning using PowerPoint presentation. The research decisions were based on the significant value that was smaller than $0.05(0.000<0.05)$, and the value of the Partial Eta Squared was 0.359 in the broad category.
\end{abstract}

C 2020 Physics Education Department, UIN Raden Intan Lampung, Indonesia.

\section{INTRODUCTION}

Indonesia is an archipelago located between two continents, Asia and Australia, and located between two oceans, namely, the Pacific Ocean and the Hindian Ocean. As a result, Indonesia is often hit by an earthquake because it is the meeting point of three tectonic plates, namely the Pacific plate, the Indo-Australian plate, and the Eurasian plate (Simkin et al., 2006).

The colliding plates can form volcanoes; thus, Indonesia becomes part of the Pacific Ring of Fire, which is the area with the most active volcanoes and earthquakes in the world (Simkin et al., 2006). Large earthquakes or volcanic eruptions at sea can sometimes trigger a tsunami. Based on the National Geophysical Data Center/World Data Service (NGDC/WDS) data in July 2020, tsunamis in Indonesia are generally triggered by shallow sea earthquakes or volcanic eruptions. A tsunami can cause many damage and casualties, especially if it hits beaches with a dense population. The Aceh tsunami disaster in 2004 was estimated to have caused 220,308 fatalities (Syamsidik et al., 2019).

Bantul, as one of the regencies in Yogyakarta, frequently experiences earthquakes because there is a subduction zone in the south of Java that has the potential of megathrust earthquake 
magnitude greater than 7.0-8.0 SR (Hartoko et al., 2016; Mulia et al., 2019). On the south coast of Java, there is a seismic gap positioned at the coordinates $\left(109^{\circ} \mathrm{E}-110\right.$ ${ }^{\circ} \mathrm{E}$ ), potentially causing an earthquake with a large scale or megathrust in the future (Kongko \& Hidayat, 2014). The scenario of a tsunami caused by the megathrust earthquake on the south coast of Java, such as Bantul, Gunungkidul, and Pacitan, has been simulated to map and determine the risk of the disaster (Kongko \& Hidayat, 2014; Mardiatno et al., 2015; Mulia et al., 2019). Based on the results of computer simulations, an earthquake with a magnitude of 8.2 can cause a tsunami with a height of 9 meters with an average distance of $2 \mathrm{~km}$. It can damage the Bantul Regency, Yogyakarta, covering an area of $20 \mathrm{~km}^{2}$ (Kongko \& Hidayat, 2014).

Disaster preparedness is one of the main focuses on the framework developed by the United Nations. The Sendai Framework for Disaster Risk Reduction 2015-2030 aims to reduce the damage caused by natural phenomena such as earthquakes, tsunamis, floods, droughts, and storms through preventive ethics (UNISDR, 2015). Several steps need to be carried out to reduce damage and casualties due to tsunami, such as socialization, simulation, construction of facilities and infrastructure, and research on geographical conditions (Sambah \& Miura, 2019; Pahleviannur, 2019; Zuhdi et al., 2019). Understanding of disasters and their mitigation needs to be informed to citizens on an ongoing basis through communities and institutions such as schools (Parwanto \& Oyama, 2014; Setiawati et al., 2013). Disaster Risk Reduction Program (DRR) through the implementation of disaster mitigation programs is a necessity that must be done through formal and non-formal education with curriculum design from Badan Standarisasi Nasional Pendidikan (BSNP) by integrating the subjects that are strongly related to disasters (Septikasari \& Ayriza, 2018).
Critical thinking skills, problem-solving, integrating environment, collaborating, and using digital tools as learning tools are required by the student in $21^{\text {st }}$-century (Alismail \& Mcguire, 2015; Scott, 2015). Students with low problem-solving skills can influence physics mastery in physics learning, such as cannot apply equations, mathematical calculations, and errors in using units (Jua et al., 2018). The poor problem-solving skills can be caused by teaching styles, learning methods, and inappropriate media (Azizah et al., 2015; Mustofa \& Rusdiana, 2016).

Smartphones with Android OS can help educators develop learning applications that contain information, simulations, explanations, and evaluation that can be accessed anytime and anywhere (Astra et al., 2015; González et al., 2014; Jengathe \& Rojatkar, 2015). Smartphones can be utilized as a medium to spread dan share information related to natural disasters and their mitigation (Nadian et al., 2015; Winarni et al., 2018). Learning by using a smartphone application as learning media can also improve critical thinking, creative thinking, and problem-solving skills (Astuti et al., 2018; Ismail et al., 2016; Mulhayatiah et al., 2019).

According to the background, disaster education is rarely carried out at disasterprone schools because there are no specific subjects regarding disaster preparedness. Teachers can use a tsunami understanding media in physics learning to understand tsunami and physics's subject together. The learning media used the Android OS to be installed on students' smartphones and can be accessed offline anywhere and anytime. The learning media is equipped with materials and evaluations on natural disaster preparedness and physics problems. This research aimed to determine the effectiveness of the implementation of tsunami understanding media through android-based physics mobile learning to improve problem-solving skills and natural disaster preparedness. 


\section{METHOD}

This research employed the quasiexperimental with non-equivalent control group design. The design can be seen in Table 1.

Table 1. The non-equivalent control group design

\begin{tabular}{cccc}
\hline Group & Pretest & Treatment & Posttest \\
\hline Experimental & $\mathrm{O}_{1}$ & $\mathrm{X}$ & $\mathrm{O}_{2}$ \\
Control & $\mathrm{O}_{1}$ & - & $\mathrm{O}_{2}$ \\
\hline
\end{tabular}

$\mathrm{O}_{1}$ is the pretests for the experimental and the control classes, $\mathrm{O}_{2}$ is the posttests for the experimental and control classes, and $\mathrm{X}$ is the applied learning media.

This research was conducted at SMA N 1 Kretek in February-March 2020. The population of this research was fifty-six students of class XI IPA. The entire population was used as research subjects consisting of 28 students of Class XI IPA 1 and 28 students of Class XI IPA 2. The research subjects were determined by random sampling.

This study aimed to determine the effectiveness of the tsunami understanding media through Android-based physics mobile learning to improve problem-solving skills and natural disaster preparedness. The problem-solving skills can be measured using five essay questions of traveling wave topic. Natural disaster preparedness can be measured using eleven essay questions. The research instruments can be seen in Figure 1 and Figure 2.

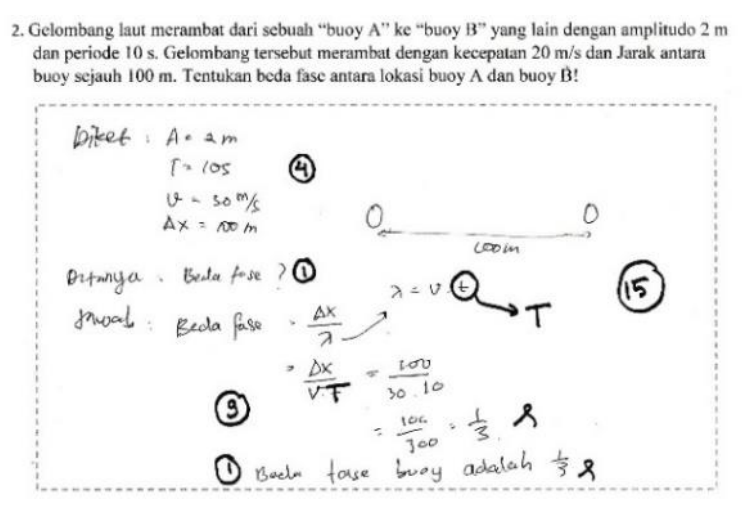

Figure 1. The display of the problem-solving skill instrument

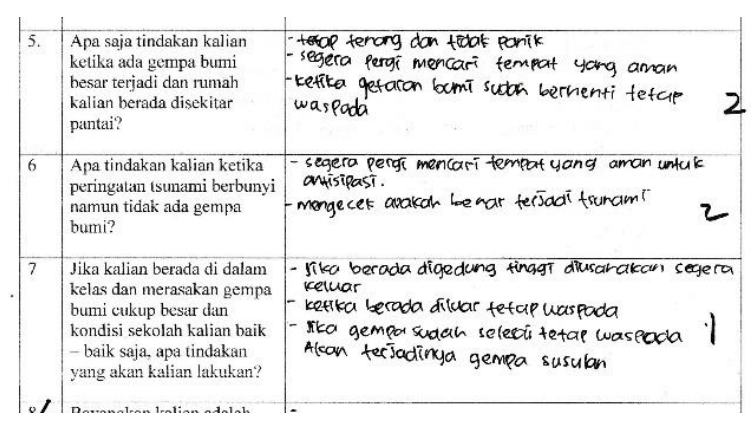

Figure 2. The display of the tsunami disaster preparedness assessment instrument

In this study, the natural disaster preparedness indicators covered the knowledge and attitudes towards the risk of natural disasters from the tsunami before, during, and after the disaster. It was focused on the socialization and training of natural tsunami disasters. The risks of natural tsunami disasters focused on the south coast of Java, especially the Bantul district's beaches. Problem-solving skills indicators referred to several indicators shown in Table 2 .

Table 2. The indicator of problem-solving skills

\begin{tabular}{ll}
\hline \multicolumn{1}{c}{ Syntax } & \multicolumn{1}{c}{ Indicators } \\
\hline Understanding & Understanding the \\
Problem & problem, explain and \\
& identify existing variables, \\
& and use appropriate \\
& quantities and units;
\end{tabular}

Planing Choosing appropriate equations to the problems, principles, and concepts of physics;

Solving Performing calculations by inputting numbers and units;

Evaluating Re-checking the answers by checking the completeness of the answers and re-checking the symbols of quantities and units by writing on the conclusion of the answers.

Experts, teachers, and peers had validated the tsunami understanding media through Android-based physics mobile learning and the research instruments used in this research. The validation results showed that 
the media and research instruments were valid and suitable for learning physics. The display of the media is shown in Figure 3 and Figure 4.

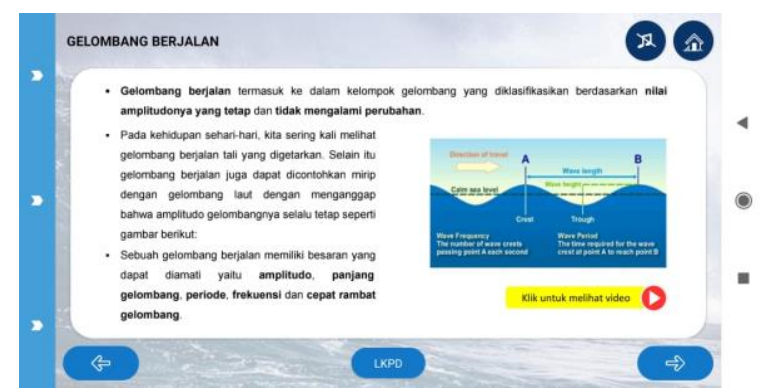

Figure 3. Page view of the tsunami understanding media through physics learning

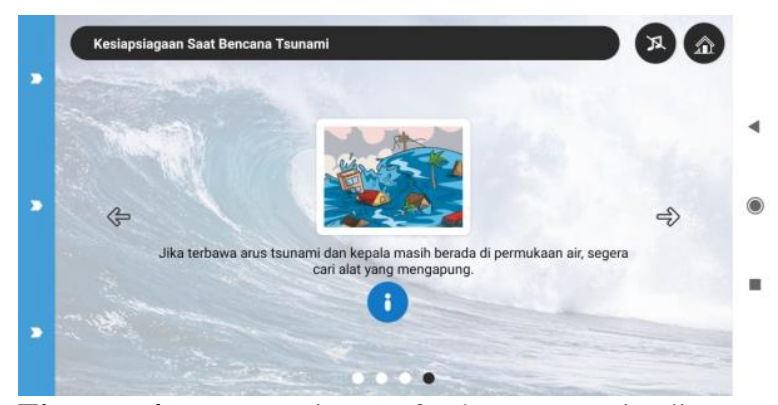

Figure 4. Page view of the tsunami disaster preparedness and its science-based reasons
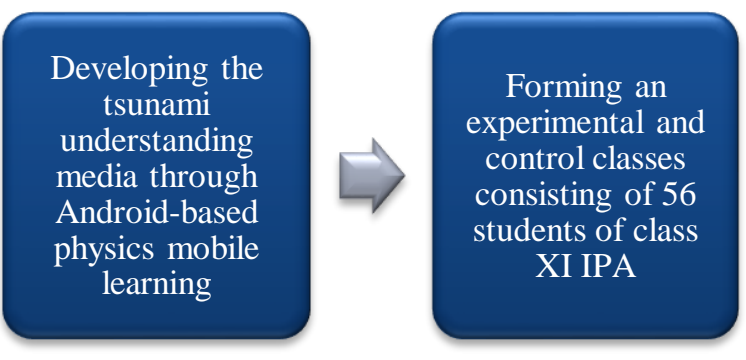

Figure 5. Research flowchart

The pretest and posttest were administered to collect the data. The following formula can determine the increase in each dependent variable using $\mathrm{N}$ gain:

$$
<\text { gain }>=\frac{X_{\text {postest }}-X_{\text {Pretest }}}{X_{\text {maks }}-X_{\text {pretest }}}
$$

Information:

$X_{\text {postest }}$ : Posttest scores
This research was conducted by giving a pretest. The tsunami understanding media through Android-based physics mobile learning was used in the experimental class, while PPT was used in the control class. Both groups used the same learning model, namely problem-based learning and learning cycle (5E). At the last meeting, a tsunami disaster simulation was conducted. Students should open the media to access the material in the experimental class, while in the control class, students must open a paperbased media. Worksheets were used to collect data and answer questions. Each group presented the results in front of the class. After all learning processes had been completed, the students were given a posttest. The research process is presented in Figure 5.

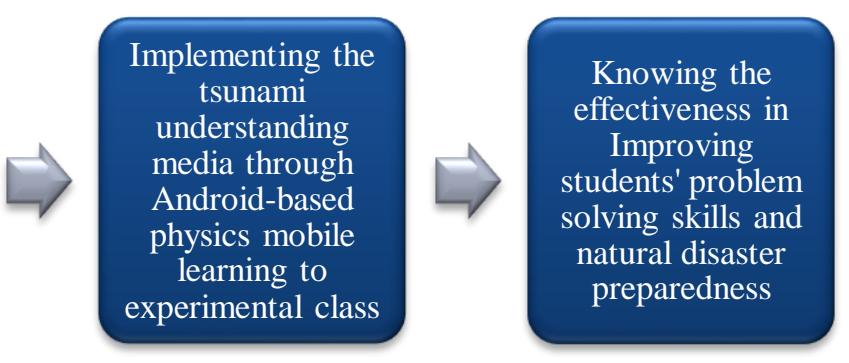

$X_{\text {Pretest }}:$ Pretest scores

$X_{\text {maks }}$ : Maximum score from the instrument

If the n-gain data is normally distributed multivariate and homogeneous, the data can be analyzed multivariate using the MANOVA analysis to determine the dependent variable's improvement.

Knowing the

ffectiveness in

students' problem

solving skills and

natural disaste 
RESULTS AND DISCUSSION The Improvement of the Problem-Solving Skills and Natural Disaster Preparedness

The improvement of students' problemsolving skills and natural disaster preparedness was obtained from the $\mathrm{N}$-gain value of pretest and posttest from each assessment instrument. The category of improvement can be seen in Table 3 (Sundayana, 2015).

Table 3. The category of $n$-gain values

\begin{tabular}{cc}
\hline N-gain value & Category \\
\hline $\mathrm{g} \geq 0,7$ & High \\
$0,7>\mathrm{g}>0,3$ & Intermediate \\
$\mathrm{g} \leq 0,3$ & Low \\
\hline
\end{tabular}

It was found that the students' frequency in improving their problem-solving skills and natural disaster preparedness based on the $\mathrm{N}$-gain category is shown in Table 4 and Table 5 .

Table 4. The category of improvement frequency in the problem-solving based on n-gain

\begin{tabular}{lcc}
\hline \multirow{2}{*}{ Category } & \multicolumn{2}{c}{ Frequency } \\
\cline { 2 - 3 } \multicolumn{1}{c}{ Experimental } & Control \\
\hline High & 23 & 10 \\
Intermediate & 5 & 18 \\
Low & 0 & 0 \\
\hline
\end{tabular}

Table 5. The Category of Improvement Frequency in Natural Disaster Preparedness Based on Ngain

\begin{tabular}{lcc}
\hline \multirow{2}{*}{ Category } & \multicolumn{2}{c}{ Frequency } \\
\cline { 2 - 3 } & Experiment & Control \\
\hline High & 27 & 20 \\
Intermediet & 1 & 8 \\
Low & 0 & 0 \\
\hline
\end{tabular}

The highest frequency of improvement can be found in the experimental class with 23 students (high category). Five students were in the intermediate category. Meanwhile, the highest frequency of natural disaster preparedness can be found in the experimental class with a frequency of 20 students (high category). Eight students were in the intermediate category. From these results, it can be concluded that the students' problem-solving abilities and natural disaster preparedness improved well.

This research was in line with other studies that integrate media disaster education, such as earthquake and landslide, in physics learning (Labibah et al., 2019; Rany et al., 2020). The physic learning integrated with natural disaster education can also improve natural disaster preparedness (Rahmawati et al., 2020). Meanwhile, this research focused on tsunami disaster. In the evaluation, the students were asked to determine the appropriate actions in the event of a tsunami under certain conditions.

Providing disaster information from pre, while, and post-disaster can increase awareness (Pahleviannur, 2019). Knowledge of tsunami disaster preparedness can be improved through the learning media. Information on risks and actions if a disaster does occur is essential in natural disaster preparedness (Rafliana, 2017; Ranke, 2016). Also, some disaster materials in learning media had been integrated with physics learning, such as the relationship between ocean waves and traveling waves, the theory of density when an object or person floats in the sea, and the hydrostatic pressure on a car door when it drifts.

This research was also in line with other studies that use physics mobile learning by integrating certain local wisdom to improve problem-solving skills (Gebze et al., 2020; Shabrina \& Kuswanto, 2018). The use of digital media as a learning media can make it easier to train problem-solving skills because students can directly see the material presented in the form of moving images or videos (Mulhayatiah, 2019).

Hesse (2015) states that problem-solving is a decision to process problems through reasoning skills. This decision is included in the evaluation of choosing the right decision when a tsunami occurs, from how to identify scenarios, decide and apply learned preparedness, and re-evaluate actions based on procedures. Besides, in solving physics problems, steps are given from what is 
known and asked for answers and apply the equation by referring to the material available in the learning media. These steps are linked to indicators in training problemsolving skills. So, through the problems displayed in the media, problem-solving skills can be improved.

\section{The Effectiveness of Problem-Solving Skills and Natural Disaster Preparedness}

The results of effectiveness research can be analyzed if the prerequisite assumptions are met.

\section{a. Normality Test}

A multivariate normality test was done by looking at the relationship between Mahalanobis distance and chi-square values. If the scatterplot for the graph between the Mahalanobis distance and chi-square tends to form a straight line with more than $50 \%$ values, it can be concluded that the population is normally distributed. The data used in the normality test were the $\mathrm{N}$-gain data of each group. The results of the analysis are shown in Table 6.

Table 6. The percentage value of the mahalanobis distance and the chi-square

\begin{tabular}{cc}
\hline Group & $\begin{array}{c}\text { The Percentage of } \\
\text { Mahalanobis Distance }<\text { Chi- } \\
\text { Square }\end{array}$ \\
\hline Experimental & $53,5 \%$ \\
Control & $53,5 \%$ \\
\hline
\end{tabular}

In the control class and the experimental class, the Mahalanobis distance value was smaller than the chi-square value (more than $50 \%$ ). The Pearson correlation was used to determine the degree of correlation between the Mahalanobis Distance and the ChiSquare. The correlation levels are shown in Table 7.

Table 7. Pearson correlation value between mahalanobis distance and chi-square

\begin{tabular}{ccc}
\hline Group & Pearson Correlation & Sig. \\
\hline Experimental & 0.979 & 0.000 \\
Control & 0.983 & 0.000 \\
\hline
\end{tabular}

Table 7 shows that sig. value was less than 0.05. thus, the scatter plot tends to form a straight line. It can be concluded that the data population of the experimental and the control classes were usually distributed.

\section{b. Homogeneity Test}

The homogeneity tests of variancecovariance matrices were analyzed using the Box-M homogeneity test to find out whether the experimental and control classes had homogeneous covariance matrices or not. The results of the Box-M homogeneity test using the SPSS 23 program are shown in Table 8.

Table 8. Box-M homogeneity test result

\begin{tabular}{cccc}
\hline Variable & Box's M & F & Sig. \\
\hline Problem- & 5.549 & 1.777 & 0.149 \\
Solving & & & \\
Skills and & & & \\
Natural & & & \\
Disaster & & & \\
Preparedness & & & \\
\hline
\end{tabular}

Based on the homogeneity test, the sig. value was equal to 0.149 . Thus, the value was higher than the significance level of 0.05. The experimental and control classes had homogeneous or equal covariance matrices.

\section{Hotelling's Trace Test}

To determine the difference in the improvement of problem-solving skills and natural disaster preparedness, the Hotelling's Trace test was used in the MANOVA test analysis. The hypotheses of the research were.

$\mathrm{H}_{0}$ : There was no significant difference between the improvement of problemsolving skills and natural disaster preparedness in the experimental class and the control class

$\mathrm{H}_{1}$ : There was a significant difference between the improvement of problemsolving skills and natural disaster preparedness in the experimental class and the control class 
The decision was determined by looking at the sig value. If it is less than $<0.05$, then $\mathrm{H}_{0}$ is rejected. On the other hand, if it is more significant than $>0.05$, then $\mathrm{H}_{0}$ is accepted. The results of the analysis are shown in table 9.

Table 9. Hotelling's trace test result

\begin{tabular}{llll}
\hline Test & F & Sig & $\begin{array}{l}\text { Partial } \\
\text { Era } \\
\text { Squared }\end{array}$ \\
\hline Hoteling's Trace & 15.143 & 0.000 & 0.359 \\
\hline
\end{tabular}

The results of the Hotelling Trace test analysis showed that the sig. The value was 0.000 , less than 0.05. Based on the hypothesis, $\mathrm{H}_{0}$ was rejected. The result showed a significant difference in problemsolving skills and natural disaster preparedness in the experimental class and the control class. The effectiveness of the media can be seen in the partial eta squared value (0.359). According to Cohen (1988), if the partial eta squared value is more than 0.14 , it has an effect size value within a broad category.

Even though both groups used the same learning model, the experimental class treatment was more effective because the students can access the learning material anytime and anywhere. Students; mobility does not depend on time, location, and space (Zhang, 2015). The benefits and advantages of a smartphone in learning are in line with McQuiggan (2015), who states that it can be effectively used outside of school because it can be accessed easily. Even though smartphones have several advantages, using smartphones as learning media in class requires extra supervision to avoid activities outside of learning, such as accessing social media and playing games.

\section{CONCLUSION AND SUGGESTION}

Learning by linking physics and natural disaster preparedness can improve problemsolving skills and knowledge about natural disaster preparedness. Tsunami understanding media through Android-based mobile learning physics is more effective in learning than learning through PPT media. For further research, teachers are expected to monitor smartphone usage in learning better. The development of similar learning media using different media types, disasters, and dependent variables can be done in future research.

\section{AUTHOR CONTRIBUTIONS}

AJA and M collected and analysed data, $M$ display data. AJA wrote the result and discussion. SS review the literature in accordance with the research and prepared research design.

\section{REFERENCES}

Adiyoso, W., \& Kanegae, H. (2017). Tsunami resilient preparedness indicators: The effects of integrating religious teaching and roles of religious leaders. In Disaster Risk Reduction in Indonesia. 561-587. https://doi.org/10.1007/978-3-31954466-317

Alismail, H. A., \& Mcguire, P. (2015). $21^{\text {st }}$ century standards and curriculum: current research and practice. Journal Education and Practice, 6(6), 150-155.

Astra, I. M., Nasbey, H., \& Nugraha, A. (2015). Development of an android application in the form of a simulation lab as learning media for senior high school students. Eurasia Journal of Mathematics, Science \& Technology Education, 11(5), 1081-1088. https://doi.org/10.12973/eurasia.2015.1 $376 \mathrm{a}$

Astuti, I. A. D., Dasmo, D., Nurullaeli, N., \& Rangka, I. B. (2018). The impact of pocket mobile learning to improve critical thinking skills in physics learning. Journal of Physics: Conference Series, 1114(1), 1-5. https://doi.org/10.1088/17426596/1114/1/012030

Azizah, R., Yuliati, L., \& Latifah, E. (2015). Kesulitan pemecahan masalah fisika pada siswa SMA. Jurnal Penelitian 
Fisika dan Aplikasinya, 5(2), 44-50.

Cohen, J. A. (1988). Statistical Power Analysis for the Behavioral Sciences. Hillsdale. Lawrence Erlbaum Associates.

Gebze, D. A., Jumadi, \& Perwati, S. (2020). Improving problem-solving ability in physics through android-based mobile learning application. Journal of Physics: Conference Series, 1440(1), 1-5. $\quad$ https://doi.org/10.1088/17426596/1440/1/012022

González, M. Á., González, M. Á., Llamas, C., Martin, M. E., Vegas, J., Martinez, Ó., Hernández, C., \& Herguedas, M. (2014). Mobile phones for teaching physics: Using applications and sensors. Proceedings of the Second International Conference on Technological Ecosystems for Enhancing Multiculturality, 349-355. https://doi.org/10.1145/2669711.26699 23

Hartoko, A., Helmi, M., Sukarno, M., \& Hariyadi. (2016). Spatial tsunami wave modelling for the south java coastal area, Indonesia. International Journal of Geomate, 11(25), 2455-2460.

Hesse, F., Care, E., Buder, J., Sassenberg, K., \& Griffin, P. (2015). A framework for teachable collaborative problem solving skills. In Assessment and Teaching of 21st Century Skills (pp. 37-56). https://doi.org/10.1007/97894-017-9395-7_2

Ismail, N. S., \& Harun, J. (2016). Supporting students' critical thinking with a mobile learning environment: A meta-analysis supporting students' critical thinking with a mobile learning environment. Proceeding of INTED2016 Conference, (pp.37463755).

https://doi.org/10.21125/inted.2016.18 99

Jengathe, G., \& Rojatkar, D. V. (2015). Use of android in education system. International Journal of Electrical and Electronics Research, 3(4), 133-137.
Jua, S. K., Sarwanto, \& Sukarmin. (2018). The profile of students' problemsolving skill in physics across interest program in secondary school. Journal of Physics: Conference Series, 1022(1), 1-8. $\quad$ https://doi.org/10.1088/17426596/1022/1/012027

Kongko, W., \& Hidayat, R. (2014). Earthquake-tsunami in south Jogjakarta Indonesia: Potential, simulation models, and related mitigation efforts. Journal of Applied Geology and Geophysics, 2(3), 18-22.

Labibah, U. N., Wilujeng, I., Sulaiman, S., \& Rahmawati, L. (2019). Androidbased physics learning media integrated landslide disaster. Jurnal Ilmiah Pendidikan Fisika Al-Biruni, 8(2), 229-236. https://doi.org/10.24042/jipfalbiruni.v0 i0.4695

Mardiatno, D., Sunarto, WF, L. R., Saptadi, G., \& Ayuningtyas, E. A. (2015). Risk mapping and tsunami mitigation in Gunungkidul area, Yogyakarta. AIP Conference Proceedings, 1658(1), 1-9. https://doi.org/10.1063/1.4915043

McQuiggan, S., Kosturko, L., McQuiggan, J., \& Sabourin, J. (2015). Mobile learning: A handbook for developers, educators, and learners. John Wiley \& Sons, Inc.

Mulhayatiah, D., Purwanti, P., Setya, W., Suhendi, H. Y., Kariadinata, R., \& Hartini, S. (2019). The impact of digital learning module in improving students' problem-solving skills. Jurnal Ilmiah Pendidikan Fisika AlBiruni, 8(1), 11-22. https://doi.org/10.24042/jipfalbiruni.v8 i1.3150

Mulia, I. E., Gusman, A. R., Williamson, A. L., \& Satake, K. (2019). An optimized array configuration of tsunami observation network off southern Java, Indonesia. Journal of Geophysical Research: Solid Earth, 124(9), 96229637.

https://doi.org/10.1029/2019JB017600 
Mustofa, M. H., \& Rusdiana, D. (2016). Profil kemampuan pemecahan masalah siswa pada pembelajaran gerak lurus. Jurnal Penelitian dan Pengembangan Pendidikan Fisika, 2(2), 15-22. https://doi.org/doi.org/10.21009/1.0220 3

Nadian, N., Nik, N., \& Sipon, S. (2015). One-stop center for disaster training information in smartphone platform: A mobile prototype. International Journal of Interactive Mobile Technologies, 9(4), 12-16. https://doi.org/10.3991/ijim.v9i4.4418

Pahleviannur, M. R. (2019). Edukasi sadar bencana melalui sosialisasi kebencanaan sebagai upaya peningkatan pengetahuan siswa terhadap mitigasi bencana. Jurnal Pendidikan Ilmu Sosial, 29(1), 49-55. https://doi.org/10.23917/jpis.v29i1.820 3

Parwanto, N. B., \& Oyama, T. (2014). A statistical analysis and comparison of historical earthquake and tsunami disasters in Japan and Indonesia. International Journal of Disaster Risk Reduction, 7(3), 122-141. https://doi.org/10.1016/j.ijdrr.2013.10. 003

Rafliana, I. (2017). Science communication for disaster risk reduction: Role of LIPI through the COMPRESS program. In Disaster Risk Reduction in Indonesia. Springer International Publishing.

Rahmawati, L., Labibah, U. N., \& Kuswanto, H. (2020). The implementation of android-based physics learning media integrated with landslide disaster education to improve critical thinking ability and disaster preparedness. Journal of Physics: Conference Series, 1440(1), 1-6. https://doi.org/10.1088/17426596/1440/1/012042

Rany, T. D., Kuswanto, H., \& Abdillah, A. J. (2020). Development of physicsbased learning media for android integrated with earthquake disaster education. Journal of Physics: Conference Series, 1440(1), 1-6. https://doi.org/10.1088/17426596/1440/1/012029

Ranke, U. (2016). Natural disaster risk management. In natural disaster risk management: Geosciences and social responsibility. Springer International Publishing.

Sambah, A. B., \& Miura, F. (2019). Geospatial analysis for tsunami risk mapping. In Advanced Remote Sensing Technology for Synthetic Aperture Radar Applications, Tsunami Disasters, and Infrastructure, (pp. 121). IntechOpen. https://doi.org/10.5772/intechopen.826 65

Scott, C. L. (2015). The futures of learning 2: What kind of learning for the 21st century (UNESCO Education Research and Foresight).

Septikasari, Z., \& Ayriza, Y. (2018). Strategi integrasi pendidikan kebencanaan dalam optimalisasi ketahanan masyarakat menghadapi bencana erupsi gunung merapi. Jurnal Ketahanan Nasional, 24(1), 47-59. https://doi.org/https://doi.org/10.22146/ jkn.33142

Setiawati, I. K., Rusilowati, A., \& Khumaedi. (2013). Pembuatan buku cerita IPA yang mengintegrasikan materi kebencanaan alam untuk meningkatkan literasi membaca dan pembentukan karakter. Jurnal Pendidikan IPA Indonesia, 2(2), 129135.

Shabrina, \& Kuswanto, H. (2018). Androidassisted mobile physics learning through Indonesian batik culture: improving students' creative thinking and problem solving. International Journal of Instruction, 11(4), 287-302. https://doi.org/https://doi.org/10.12973/ iji.2018.11419a

Simkin, T., Tilling, R. I., Vogt, P. R., Kirby, S. H., Kimberly, P., \& Stewart, D. B. (2006). This dynamic planet: World 
map of volcanoes, earthquakes, impact craters and plate tectonics. In IMAP. https://doi.org/10.3133/i2800.

Sundayana, R. (2015). Stastitika penelitian pendidikan. Bandung: Alfabeta.

Syamsidik, Nugroho, A., Oktari, R. S., \& Fhmi, M. (2019). Aceh pasca lima belas tahun tsunami: Kilas balik dan proses pemulihan. Tsunami and Disaster Research Center (TDMRC).

UNISDR (2015). Sendai framework for disaster risk reduction 2015 - 2030 . United Nations Publication .https://doi.org/10.1093/oxfordhb/9780 199560103.003.0005

Winarni, E. W., Purwandari, E. P., \& Hervianti, Y. (2018). Mobile educational game for earthquake disaster preparedness in elementary school. Journal of Engineering and Applied Sciences, 13(7), 2612-2618.

Zhang, Y. A. (Ed.). (2015). Handbook of mobile teaching and learning. Springer.

Zuhdi, M., Makhrus, M., Sutrio, S., \& Wahyudi, W. (2019). Sosialisasi tentang mitigasi bencana tsunami dan gempa lombok di jempong baru, sekarbela, Mataram. Jurnal Pengabdian Magister Pendidikan IPA, 2(1), 6-10. https://doi.org/10.29303/jpmpi.v2i1.31 6 